\title{
MULTINATIONAL FIRMS AND THE INTERNATIONALIZATION OF GREEN R6D: A REVIEW OF THE EVIDENCE AND POLICY IMPLICATIONS
}

J. NOAILLY D. RYFISCH 


\title{
Multinational Firms and the Internationalization of Green R\&D: A Review of the Evidence and Policy Implications
}

\author{
Joëlle Noailly ${ }^{1, a}$ and David Ryfisch ${ }^{b}$ \\ ${ }^{a}$ Graduate Institute of International and Development Studies, Geneva, Switzerland \\ ${ }^{\text {b }}$ Climate Change and Sustainability Division, Inter-American Development Bank, Washington D.C., USA
}

December 2014

\begin{abstract}
This paper presents novel empirical evidence on the internationalization of green R\&D by multinational firms (MNCs), as measured by patents data. Using data on inventors' addresses for the set of 1,200 MNCs firms patenting in green technologies over the 2004-2009 period, we find that about $17 \%$ of green patents result from MNCs R\&D investments conducted outside their home countries. MNCs tend to locate their foreign green R\&D activities in other OECD markets and in China, in particular in lightings and solar technologies. The empirical analysis reveals that the probability of conducting green R\&D abroad increases with the host country's stringency of environmental regulation, market size and (green) R\&D intensity. Also, relatively lower wages for scientists and engineers, and stronger protection for intellectual property rights in the host country increase the likelihood for MNCs to offshore green R\&D. The paper concludes by discussing the policy implications of this changing global innovation landscape.
\end{abstract}

\section{Introduction}

This paper aims to shed light on the internationalization of research and development in green technologies, as reflected in the global R\&D location decisions of multinational corporations (MNCs). In recent years, multinational firms have been increasingly expanding their R\&D activities outside their home countries, thereby challenging the standard view in economics that assumed that MNCs would keep R\&D and innovation close to home, as part of their headquartered operations. Between 1995 and 2003, the share of the R\&D budget spent outside

\footnotetext{
${ }^{1}$ Corresponding author: joelle.noailly@graduateinstitute.ch, Tel: +41229086222 , Adress: CIES, Graduate Institute, PO Box 136, 1211 Geneva 21, Switzerland. We acknowledge funding from the European Commission Marie Curie Research Grant (GREENSPILL project). We are grateful to Ivan Hascic (OECD) for providing me with the WEF Environmental Policy Index data as well as Roger Smeets (Rutgers Business School) for providing us with the IPR data.
} 
the home country by European multinationals increased from $25 \%$ to $44 \%$ according to a survey by Reger (2002). ${ }^{2}$ While most R\&D investment still goes to developed countries, non-OECD countries, such as China and India are attracting an increasing amount of R\&D investment (UNCTAD, 2005; OECD, 2008).

This changing innovation landscape involves all technologies and thereby green technologies that aim to reduce the pollution intensity of production processes and consumption patterns (e.g. renewable energy, electric and hybrid cars, energy-saving lightings, etc). As green technologies tend to be concentrated in the hands of firms in the developed world (Dechezlepretre et al, 2011; World Bank, 2012), better understanding how multinational firms organize their green innovation activities worldwide is important to ascertain how green technologies may diffuse to the rest of the world. The economic literature emphasizes the role of knowledge spillovers from MNCs to local firms, as an important channel of technology transfers (Keller, 2004). Since R\&D spillovers tend to be very geographically localized, due to the tacit nature of knowledge (Jaffe, 1986), attracting R\&D investments from MNCs may generate important technology transfers and economic benefits to local firms.

In this study, we aim to provide some first empirical systematic evidence on the globalization of green R\&D, a phenomenon for which there is so far only anecdotal evidence. The case of General Motors who opened in November 2012 a new GM China Advanced Technical Center in Shanghai, as part of its global network of R\&D labs, illustrates this new phenomenon. The new GM research center in China employs 300 scientists who focus on green technologies related to lightweight materials and battery cells for the development of hybrid, plug-in hybrid, and electric vehicles. In the press, Kevin Wale, Director of GM stated that the new technical center "will ensure that GM keeps up with the needs of our local customers through the development of cutting-edge automotive technology that is cleaner, more efficient and

\footnotetext{
${ }^{2}$ For US and Japanese firms, the share increased from 23 to $35 \%$ and from 5 to $15 \%$, respectively
} 
affordable." John Du, Director of the technical center, motivated further the decision to open this new R\&D lab in China by the abundant supply of scientists and engineers in China ("China now ranks first in the world in the number of PhD candidates, and these are talents we want to attract into the GM R\&D and engineering workforce"), the proximity to Asian companies in Korea and Japan leading the world in electric car battery research, China's resources of magnesium used for batteries and light-weight steel, and the presence of a large number of producers of automobile parts in China. ${ }^{4}$

The aim of the current study is to provide insights on the geographic distribution of MNCs' green innovation activities and to analyze empirically the main motives of MNCs to conduct green R\&D abroad. The central research question is: what drives the globalization of green R\&D? - or in other words, what are the determinants affecting MNCs' green R\&D location decisions? To answer this question, we use patents data at the firm level for about 1,200 multinationals patenting in green technologies over the 2004-2009 period.

The article is organized as follows. Section 2 reviews the literature on the determinants of the location of innovation activities and discusses the case of green R\&D in particular. Section 3 presents the data used in this study and provides some descriptive analysis on the international geographic distribution of green R\&D by multinational firms. Section 4 describes the empirical methodology and results. Section 5 concludes and discusses the policy implications of the globalization of green R\&D, both at the national and international level.

\section{Literature review}

In this section, we combine several strands of literature, i.e. the literature on the globalization of R\&D in international business and management, the literature on trade and FDI, and the

\footnotetext{
${ }^{3}$ http://media.gm.com/media/us/en/gm/news.detail.html/content/Pages/news/us/en/2011/Sep/0921_china.html

${ }^{4}$ http://www.reuters.com/article/2012/11/29/us-autos-china-gm-idUSBRE8AS09920121129
} 
literature on the international diffusion of green technologies in environmental economics, to discuss MNCs' main motives for locating green R\&D investments outside their home countries.

Although there has been no study so far looking at the globalization of green R\&D activities in particular, the literature on $R \& D$ internationalization in the field of international business and management provides useful insights to understand MNCs' motives for conducting R\&D outside their home countries. This literature mainly relies on case studies of MNC firms and business surveys (see Hall, 2011, and Narula and Zanfei, 2005 for a review), although some papers have also looked at the international distribution of firms' inventive activities using patents data just as we do (Cantwell, 1995; Dachs and Pyka, 2010; Harhoff and Thoma, 2010). Cantwell (1995) used US patents data to investigate the role of foreign-owned firms in US innovation activities. Harhoff and Thoma (2010) extend Cantwell's work to look at MNCs' patenting activity worldwide from 1986 to 2005 . They find that in OECD countries about $10 \%$ of inventors are employed by a foreign company, with a higher share for European countries. They document that the geographical concentrations of inventors has been decreasing over time. Regarding MNCs' strategies, this literature identifies two key motives for conducting R\&D abroad: 1) adaptive R\&D and 2) technology-sourcing.

Adaptive R\&D refers to the need for MNCs to adapt their products to specific local markets, thereby supporting their local sales and production activities in the host countries. Being close to consumers is an asset for better understanding local demand and offering adapted products. In the literature, this strategy is also referred to as 'asset-exploiting R\&D' (Dunning and Narula, 1995) or home-base-exploiting (HBE) R\&D (Kuemmerle, 1999), since the firm seeks to exploit existing technology developed at home into new market conditions (Hakanson and Nobel, 1993; Odagiri and Yasuda, 1996). When adaptive R\&D is the main motive for R\&D offshoring, the main determinant affecting firms' location choices is the level of demand in the local market. Dachs and Pyka (2010) use European Patent Office (EPO) patents from the period of $2000-2005$ and find that cross-border patenting activities are significantly 
higher when the host market is larger. Firms may find it easier to cover their cost of adaptive R\&D in larger markets with higher demand and better sales prospects. Patel and Vega (1999) look at US patenting in high technology fields. They find that in a majority of cases firms tend to locate their technology abroad in the core areas where they are strong at home, suggesting that adapting products to suit foreign markets and providing technical support to local production facilities remains a major factor underlying the internationalization of R\&D.

The second main motive of MNCs for conducting R\&D abroad - technology sourcing refers to the fact that MNCs may want to source local knowledge which is not available at home. Firms may want to improve their existing assets or to acquire new knowledge, for instance by looking for knowledge that is complementary to their home-based knowledge, through their foreign-based R\&D facilities. In the literature, this strategy is coined 'technology-seeking' or 'technology-augmenting' (Dunning and Narula, 1995) since firms want to augment their knowledge-base by sourcing new technologies abroad. A location that is home to a major competitor may attract other MNCs in the same industry. By opening up an R\&D laboratory close to a competitor, the firm hopes to benefit from knowledge spillovers and to tap into the competitor's knowledge base. As emphasized in the economic literature on R\&D spillovers, the role of geographic proximity and face-to-face interactions between scientists is critical for effective technology transfer to take place (Jaffe, 1986; Henderson et al, 1996). Both MNCs and local firms can thus greatly benefit from concentrating their R\&D activities in the same location. Griffith et al (2004) show that foreign research labs located on US soil have benefited a great deal in terms of total factor productivity of the growth of the US knowledge stock. Harhoff et al (2012) look at data from German companies engaging in R\&D cooperation with US companies over the 1992-2003 period and also find that such cooperation - in particular in the form of copatenting activities - generated higher TFP growth for both German and US firms.

When technology-sourcing is the main motive for locating R\&D overseas, MNCs will be attracted to countries with high technological capabilities, i.e. with a good supply of knowledge 
and R\&D infrastructure. Factors such as the quality and specialization of local universities and research institutions, the quality and size of the supply of R\&D personnel, the size of national innovation systems, and the possibility to collaborate with research partners within R\&D clusters are all important factors in MNCs' R\&D location choices (OECD, 2008; Hall, 2011). In interviews with multinationals, Kuemmerle (1999) finds that, when considering opening an R\&D lab, managers look at the presence of outstanding individual researchers, hoping to tap into a highquality supply of graduate students. Lewin et al (2009) find that the shortage of highly skilled science and engineering talent in the US is the most important explanatory factor for offshoring innovation by US firms. Although there is no evidence specific to green R\&D activities, the quality of the scientific infrastructure will be equally important to green technologies. Green innovation presents specific characteristics, as it builds upon a broad set of diverse technologies. Green technology is linked to science in various fields such as chemical engineering, chemistry, material sciences, physics, biology, agriculture, etc (OECD, 2010). Using patents citations, Noailly and Shestalova (2013) also find that renewable energy technology relies to a large extent on technology developed outside the field of power generation. Hence, the development of cutting-edge green technologies will require that MNCs source a very diverse range of knowledge globally.

Since green know-how is nowadays concentrated in developed countries, technologysourcing motives may be more important for these countries than for developing economies. The literature generally tends to find that access to advanced technological knowledge and R\&D resources appears to be a more important motivation for R\&D investment in the US and Europe than in less developed countries. Chung and Yeaple (2008) find that firms seek out similar R\&D activity to combine with their own and, therefore, that industries with greater technical similarity to the United States are more attractive to US firms expanding abroad. Odagiri and Yasuda (1996) look at R\&D conducted abroad by Japanese firms in the 1980 s and find that Japanese firms' R\&D investments in the US and Europe were motivated by technology-sourcing motives, 
while their main motivation for investing in Asia was related to adaptive R\&D and technologyexploiting motives.

Next to technology-exploiting and technology-sourcing motives, the literature on FDI location choices in international trade emphasizes the role of cost-related factors that are also likely to matter for MNCs' R\&D location decisions. MNCs might consider labor costs in deciding where to locate R\&D. Foreign investors would locate in countries where the input factors they use are cheaper than at home (Brainard, 1997). Lower wages for scientists and engineers located abroad rather than at home might thus weigh into MNCs' location decisions, at least when the quality of R\&D personnel is comparable across countries. In the trade literature, the importance of wage differentials for offshoring production activities has been challenged by the finding that a majority of FDI originates from and locates in developed countries. Regarding R\&D location, there is only weak evidence that differences in the cost of R\&D personnel are a major driver for the internationalization of R\&D. Nonetheless, wage differences gain importance when firms consider locating innovation activities in emerging and developing economies (Thursby and Thursby, 2006). Besides labor costs, Intellectual Property Rights (IPR) mechanisms also matter for cross-border patenting. Stronger IPRs may help to render patenting activities in the host country more attractive. Indeed Thursby and Thursby (2006) find that weak IPRs enforcement is an important deterrent for locating R\&D in emerging economies. Weak IPRs increase the risk of imitation; nonetheless, when MNCs follow technology-sourcing motives, they may not be pursuing a strategy of marketing the technology directly in the local country, and in this case IPRs policies may be less relevant. Finally, the trade literature points out the existence of a proximity-concentration tradeoff between the advantages of locating near the market (lower transport costs) and the benefits of concentrating production in one location, especially in sectors with economies of scale (Brainard, 1997). In the case of overseas R\&D, locating R\&D labs further away from the home country may involve increasing costs of coordinating geographically-dispersed R\&D activities. Transferring knowledge over greater distances is 
particularly difficult due to the tacit nature of knowledge and may involve significant costs. Instead, transportation costs have a limited role for R\&D location decisions. Nonetheless, if R\&D is meant to support adaptive local production intended for the local market, the advantages of being near the local market might outweigh the costs.

With regards to the specific case of green R\&D compared to general R\&D, the environmental economics literature emphasizes the fact that green technologies may be different from other technologies since in the absence of policy support, the private sector will always have too little incentives to invest in green R\&D, due to the presence of the environmental externality. Indeed, an important condition for the emergence of local demand for green technologies is the enforcement of local environmental regulations in the host countries, providing incentives to buy environmental goods. Since there is no price on polluting goods, the demand for environmental goods and technologies will always be too low in the absence of public policies. Hence, the level of environmental policy in the host country is likely to be a critical factor in creating a local market for environmental goods for which adaptive R\&D will be needed. The lack of demand for green products in emerging and developing countries may not make these countries attractive to MNCs' green innovation activities. Several studies have looked at the determinants of green technology transfers using patents data (Dechezlepretre et al. 2012; Bosetti and Verdolini, 2012; Dekker et al, 2012). Looking at multiple patent filings to proxy technology transfers ${ }^{5}$, the main results from these studies indicate that barriers to patent flows across countries tend to be the absence of local environmental policies, a low absorptive capacity among recipient countries, barriers to trade, weak IPRs, and geographical distance. So far, there has been no study looking specifically at the internationalization of green R\&D. One

\footnotetext{
${ }^{5}$ Using patent filings to measure technology transfer is subject to controversies as filing a patent application at a patent office is no guarantee that the technology will actually be exploited in that market and there is some evidence that patents filings abroad are often used as a strategic tool to block products or competitors in international markets (Cohen et al., 2000, Hall and Ziedonis, 2001). In our case, since we consider the firm's patents invented - instead of filed - in foreign countries, we may be able to better capture actual technology transfers, as the technology has been invented in the host country. Nonetheless, measuring knowledge spillovers from the presence of MNCs research labs in foreign countries is an empirical question left for further research.
} 
exception is Hascic et al (2012) who look at worldwide co-inventions in green technologies, i.e. patents for which inventors located in different countries have collaborated. They find that international collaboration on patents represents between 4 and $10 \%$ of all green patents, depending on the maturity of the technologies (ranging from $3.9 \%$ for wind technologies to $10 \%$ for biofuels). They also find that multilateral energy technology initiatives tend to increase the number of co-inventions in green patenting.

\section{Data}

\subsection{Construction of the patent dataset}

The main data source for the analysis is the ORBIS dataset of Bureau van Dijk, which is a commercial database, including administrative information on 120 million companies around the world (updated as of December 2013). The information is drawn from over 40 different information providers using a multitude of data sources, typically national and/or local public institutions collecting data to fulfill legal and/or administrative requirements. The most recent version of ORBIS includes additional information on patents associated with firms. We focus on the subsample of firms that have been granted at least one green patent over the period of 2004-2009.

\section{Patents}

We use patent data to measure innovations in green technologies (Popp, 2002; Johnstone et al, 2010). The advantages and limitations of patents as a measure of innovation have been discussed at length in the literature. A main caveat of working with patents is that not all inventions are patented, as for strategic reasons firms may prefer not to disclose some valuable information in a patent. Also, the value of patents is very heterogeneous: only few patents will lead to successful commercial applications, while many will in the end never be used. The 
quality of a patent can be proxied by different indicators: whether a patent has been granted or not, the number of citations received by the patent, the family size of the patent (i.e. the number of equivalent patent filings at various patent offices). Nonetheless, despite the pitfalls of patents highlighted in the literature, patents have a close (if not perfect) link to invention and are strongly correlated with other indicators of innovative activity, such as R\&D expenditures or new product introductions. For our purpose the main advantage of using patent data is that this data is highly disaggregated and is available at the firm and technology level. In addition, they contain valuable information for our analysis, namely the address of the inventor, which tells us the location of the R\&D laboratory where the patent was developed.

Patents data is extracted directly from the ORBIS dataset, which contains information on patents derived from the European Patent Office's (EPO) PATSTAT dataset. We consider all patents that have been granted to a firm across 80 patent offices worldwide, selecting only the priority patent in the case of multiple filings of patent applications. A major advantage of using the ORBIS dataset is that patent applicants' names have been harmonized and corrected for variations in spelling in order to be matched with business register data. Although there may be some concerns about comparing patents of heterogeneous value filed at different patent offices, we chose not to reduce our sample to only patents of higher value filed in several patent offices (claimed priorities or triadic family patents) in order to provide the most complete possible picture of all of a firm's R\&D locations. If a firm is conducting R\&D abroad with the purpose of developing technologies for the local market, this invention may only be filed for protection in the host country and not in other patent offices. Overall, we are confident that our sample mainly captures high quality patents, since we focus on granted patents of large multinational firms that could be matched with the business register data in ORBIS, thus excluding patents from individuals.

Building on previous work from the OECD (see for instance: Johnstone et al., 2010), we use International Patent Classification (IPC) codes to select patents in 25 green 
technologies, including technologies in air pollution management, energy-saving lighting, electric and hybrid vehicles, cement manufacturing, heating, insulation, renewable energy (wind, solar, hydro, ocean, biomass, geothermal and waste), energy efficient fossil-fuel electricity production (coal gasification, improved burners, fluidized bed combustion, improved boilers for steam generation, improved steam and compressed-ignition engines, improved gas turbines, superheaters, cogeneration technologies), and storage technologies.

\section{$R \& D$ locations using inventors' address}

We extract information on the international distribution of firms' R\&D locations by using inventors' addresses as recorded in the firms' patent applications. Hence, we count the number of patent applications per firm per year classified by inventor country - as extracted from the inventor's residential address - in selected areas of environmental technologies. We use the year of the application priority date, which is the date closest to the point of invention. We compute fractional counts to count the number of inventors per country when one patent has several inventors. ${ }^{6}$ As a result, we observe firms that have innovative activities in green technologies in multiple countries. We define a firm's home country as the country where the firm is headquartered. Overall, by comparing the location of firms' inventors on the green patent applications and the home location of the parent firm, we are able to measure the extent to which green R\&D is taking place outside the home country of the firm. A firm may have patents only in its home country or both in its home country and in at least one foreign country. In the remaining analysis, we will define an 'offshoring' firm as a firm that has at least one green patent invented outside its home country.

\section{Ownership and financial information}

\footnotetext{
${ }^{6}$ We also use fractional counts when one patent has several applicant firms and when one patent belongs to several green technology classes
} 
The firms holding green patents may be subsidiaries of larger firms. Hence, we match these firms to their ultimate parent firm using information on Global Ultimate Owner information in ORBIS. A parent firm is identified as the Global Ultimate Owner if it owns at least $25 \%$ of the subsidiary firm.

\subsection{Descriptives on green R\&D offshoring}

\section{Firms}

We focus on the subsample of 1,200 MNCs that conducted green R\&D offshoring activities over the period of 2004-2009. Table 1 lists the top-15 firms according to the number of patents invented abroad. Philips, headquartered in the Netherlands, is the firm with the largest number of green patents invented abroad. Overall, about $60 \%$ of all its green patents, mainly in lighting technologies, are invented abroad with inventors located in China, Germany, and the US. Most of the top-15 firms are from OECD countries, with only two Taiwanese firms from outside the OECD. Regarding green offshoring R\&D locations, Table 1 shows that several of the top-15 firms (e.g. Philips, Renault, Vestas, and BASF) have research centers in China. Finally, Japanese firms tend to offshore only a modest amount of green R\&D $(15 \%$ and $5 \%$ of Panasonic and Toyota's green patent portfolios, respectively), a fact commonly found in the literature on the globalization of R\&D. Overall, however, since Japanese firms are filing a very large number of green patents (e.g. 1547 granted patents for Toyota over 2004-2009), these small shares still translate in relatively large numbers of green patents invented abroad in absolute terms. 
Table 1: Top-15 firms offshoring green patents

\begin{tabular}{lllllllll}
\hline & Name & Home & Npat & Noff & Share & $\begin{array}{l}\text { Inv. } \\
\text { Countries }\end{array}$ & Technologies \\
\hline $\mathbf{1}$ & KONINKLIJKE PHILIPS N.V. & NL & 625 & 368 & 0.59 & CN, DE, US & Lights \\
$\mathbf{2}$ & SIEMENS AG & DE & 560 & 335 & 0.60 & US, DK, GB & Wind, Cycles \\
$\mathbf{3}$ & RENAULT & FR & 731 & 297 & 0.41 & JP, CN & Vehicles, Air Pollution \\
$\mathbf{4}$ & BOUYGUES SA & FR & 313 & 278 & 0.89 & CH, US, DE & Cycles, Air Pollution, Burners \\
$\mathbf{5}$ & GENERAL ELECTRIC & US & 1237 & 260 & 0.21 & DE, IN, NL & Wind, Lights, Air Pollution \\
$\mathbf{6}$ & VESTAS WIND SYSTEMS A/S & DK & 421 & 184 & 0.44 & CN, ES, GB & Wind \\
$\mathbf{7}$ & BASF SE & DE & 212 & 139 & 0.65 & US, CN, KR & Air Pollution, Storage \\
$\mathbf{8}$ & FORD MOTOR CO & US & 612 & 126 & 0.21 & GB, DE, SE & Air Pollution, Vehicles \\
$\mathbf{9}$ & UNITED TECHN CORP & US & 363 & 117 & 0.32 & CA & Cycles, Turbines \\
$\mathbf{1 0}$ & AU OPTRONICS & TW & 311 & 117 & 0.38 & CN & Lights \\
$\mathbf{1 1}$ & PANASONIC CORPORATION & JP & 672 & 103 & 0.15 & CN & Storage, Lights, Solar \\
$\mathbf{1 2}$ & SAINT GOBAIN SA & FR & 220 & 88 & 0.40 & DE, US & Insulation, Solar, AirPollution \\
$\mathbf{1 3}$ & HON HAI LTD. & TW & 111 & 84 & 0.75 & CN & Lights, Solar \\
$\mathbf{1 4}$ & DAIMLER AG & DE & 167 & 79 & 0.48 & US, JP & Air Pollution, Vehicles \\
$\mathbf{1 5}$ & TOYOTA MOTOR & JP & 1547 & 76 & 0.05 & CN, US & Vehicles, Air Pollution \\
\hline & & & & & & & \\
\hline
\end{tabular}

Figure 1 shows the distribution of green offshored patents over the period of 2004-2009 by the firm's country of origin. Figure 1a ranks the countries by the total number of patents invented abroad, while Figure $1 \mathrm{~b}$ ranks the countries after correcting for the size of the country (number of offshored patents per GDP unit). Figure 1a shows that US companies are responsible for the largest number of green granted patents invented abroad, before Japanese, French, German and Dutch firms. China reaches the 18 th position. Looking at Figure $1 \mathrm{~b}$ which takes country size into account, we find that small outward-oriented countries such as the Netherlands, Denmark, Luxembourg, Ireland and Switzerland are the most active countries in the internationalization of green R\&D. 
Figure 1. Countries of origin

a) per number of green offshored patents

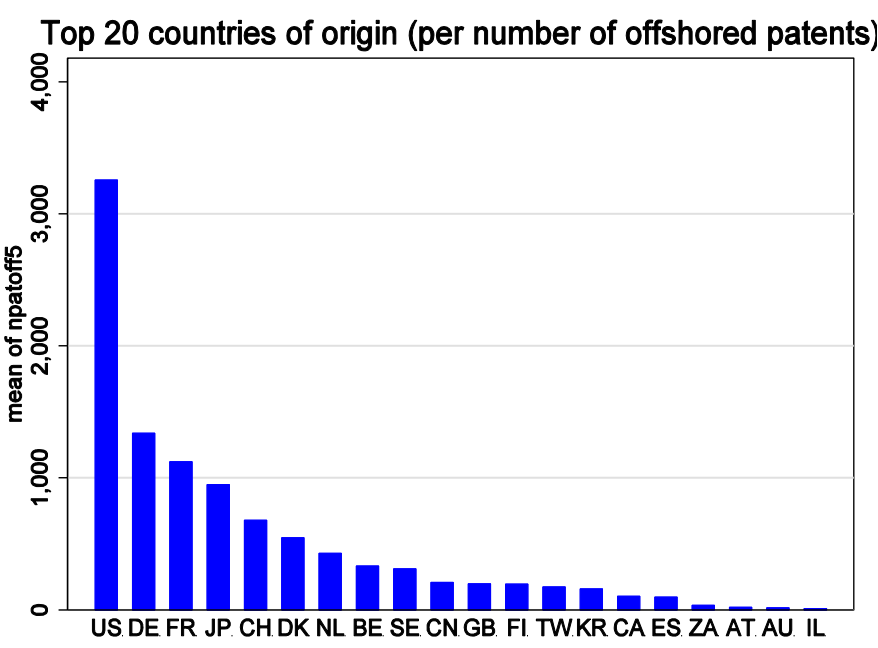

b) per number of green offshored patents per GDP unit

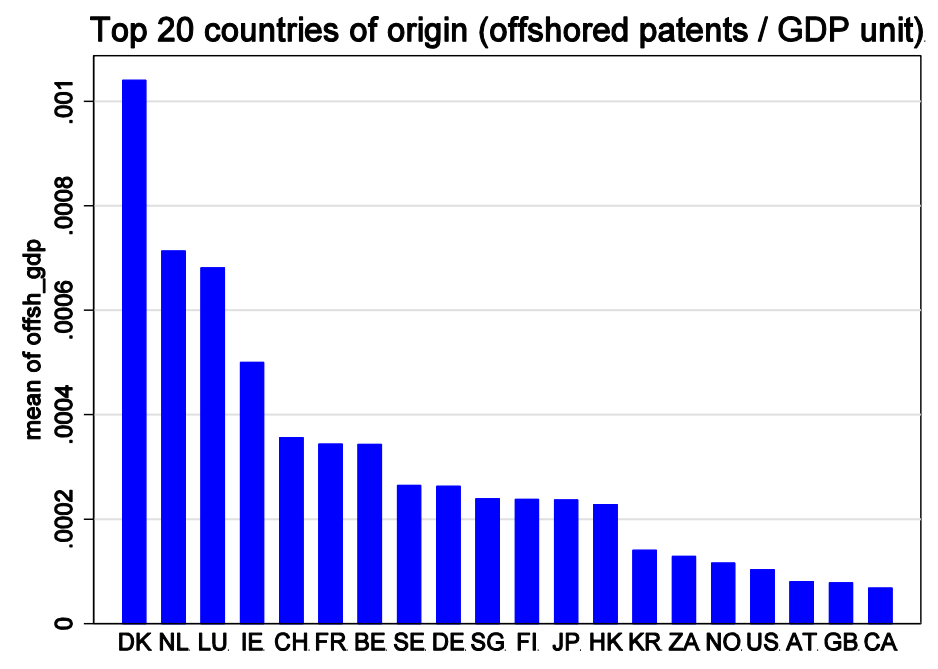

\section{Types of green patents offshored}

Over the 2004-2009 period, the sample includes about 40,000 green patents, among which 7,000 (about 17\%) have been invented outside the firm's home country. Figure 2 displays the share of patents invented abroad per type of green technology. Cycles and wind technologies have the highest share of patents invented abroad (above $25 \%$ ). 
Figure 2. Green patents invented abroad per type of technology (share in total number of patents)

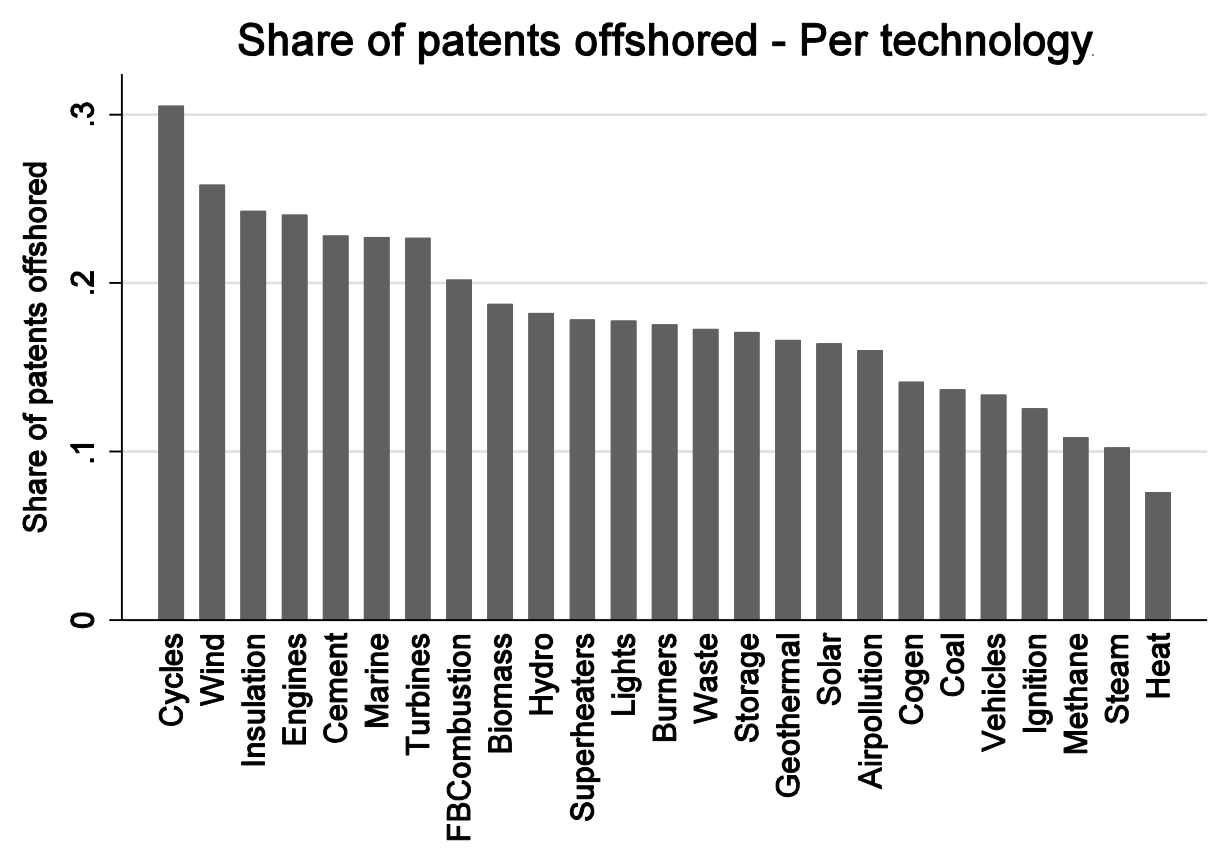

\section{Location choices}

Figure 3 depicts the distribution of green offshored patents by destination country, while Figure 4 maps the worldwide geographic distribution of offshored green patents. China, the US, and Germany are the top-destination countries when looking at the total number of green patents offshored in Figure 3. 
Figure 3. Countries of destination per number of green offshored patents

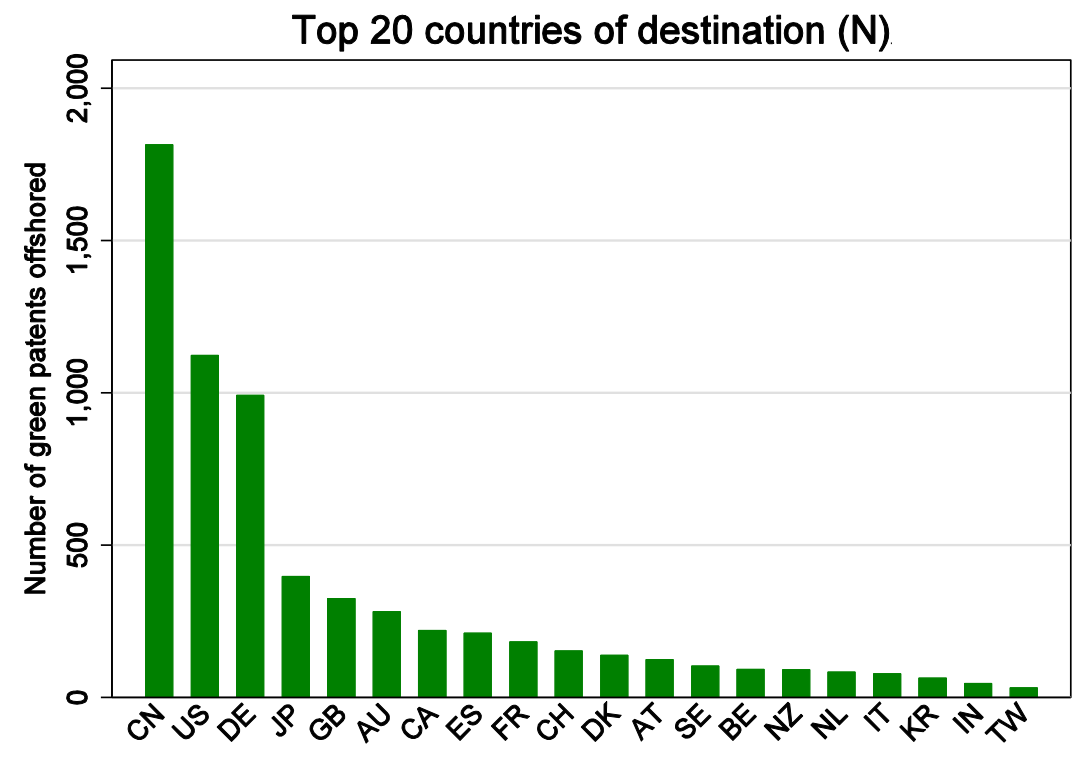

Figure 4. Worldwide map - destination countries of green offshoring R\&D

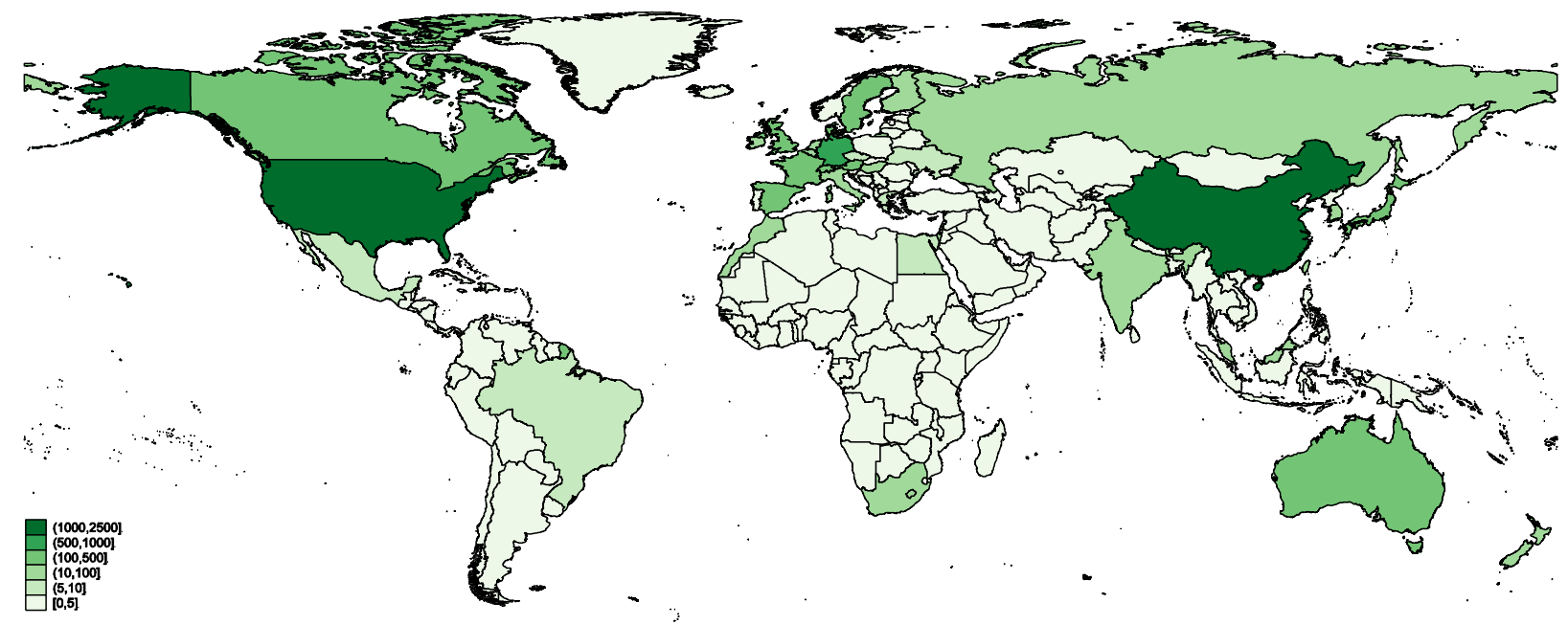


To illustrate disparities among technologies, Figure 5 shows the distribution of MNCs' inventor countries for the top-5 green technologies: Air pollution, Lights, Vehicles, Solar and Wind energy. China ranks first in Lights and Solar technologies. India reaches the top-10 destination countries in Wind technologies.

Figure 5. Top-10 destination countries in specific green technologies
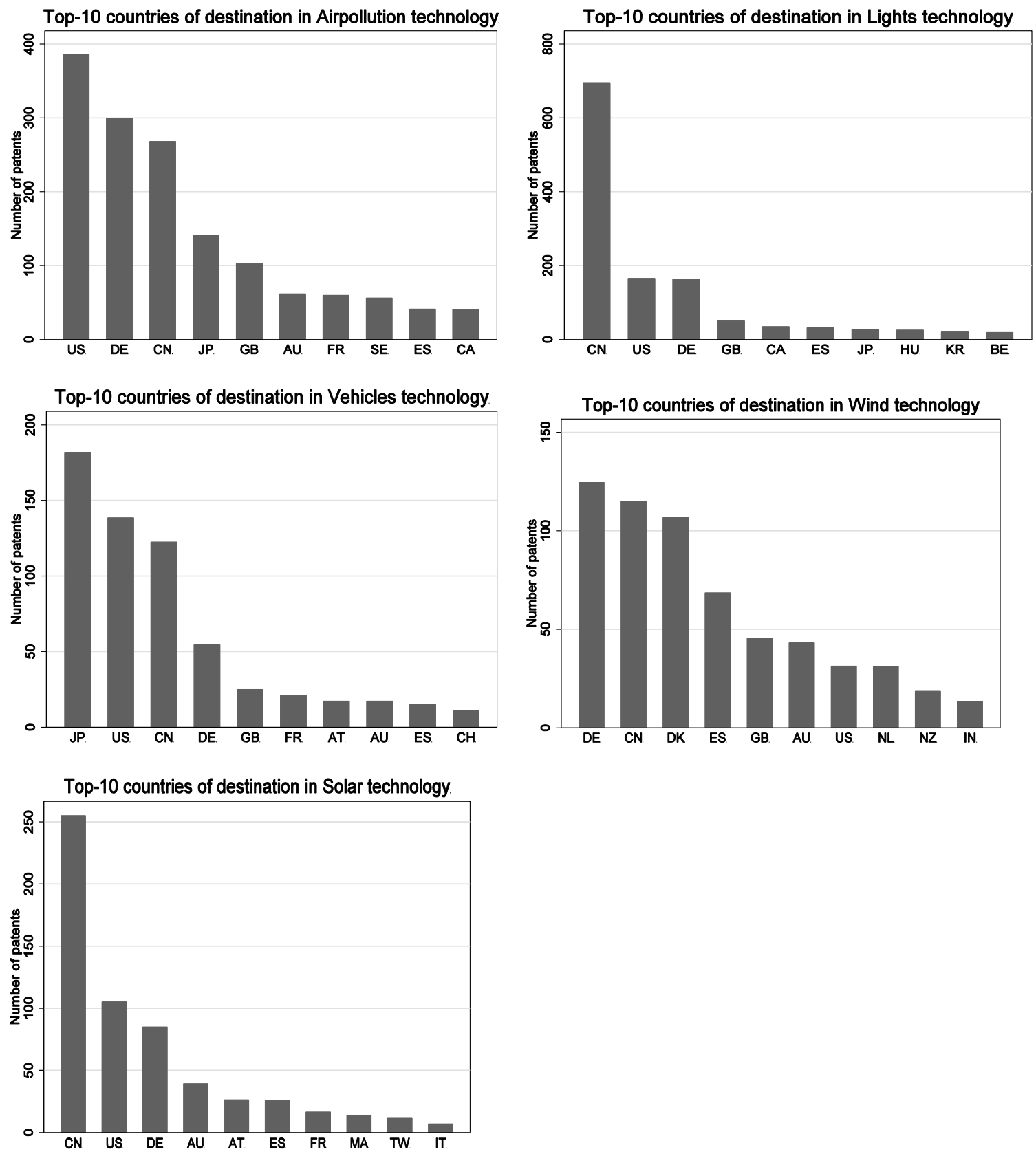
Figure 6 displays the distribution of country-pairs in green innovation offshoring. A large number of green offshoring is conducted by Japanese and Taiwanese firms with inventors in China and by bilateral activities between Germany and the US.

Figure 6. Green offshoring activities per country-pairs (per number of green offshored patents)

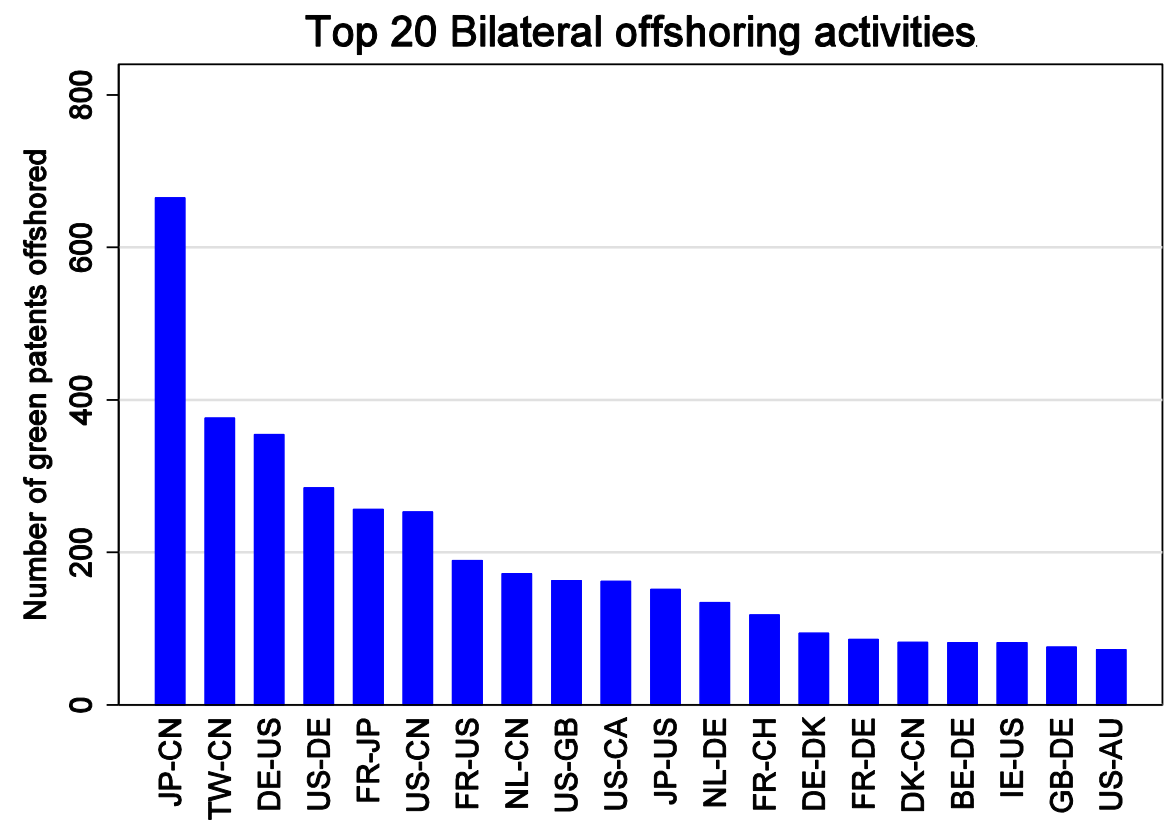

Finally, Figure 7 plots the relationship between the level of environmental policy in host countries and green offshoring activities by MNCs. We include information on the level of environmental policy stringency as measured by the Environmental Policy Index based on the World Economic Forum's 'Executive Opinion Survey'. ${ }^{7}$ Until 2008, businesses, business associations, and universities in over 100 countries were asked to respond to questions about the countries' environmental policy, scaling it on the scale from 1 (less stringent) to 7 (more stringent). The compiled index is based on three elements of the survey: stringency, flexibility, and predictability of the environmental policy (see Kellenberg (2009) for an application of this index to measure environmental policy stringency). Figure 7 shows a positive correlation between the location of

\footnotetext{
${ }^{7}$ We thank Ivan Hascic from the OECD for providing us with this dataset.
} 
green offshored patents and the stringency of environmental policy in the host country. Although China attracts green R\&D activities of MNCs, it only appears on the left side of Figure 9, due to its weak level of environmental regulations, suggesting that other factors may be at play to explain the attractiveness of China for green R\&D. Morocco (country code MA) is another country where MNCs offshore a relatively high amount of green R\&D despite its relatively low level of environmental regulation.

Figure 7: Relationship between environmental policy index and green offshored patents per GDP unit

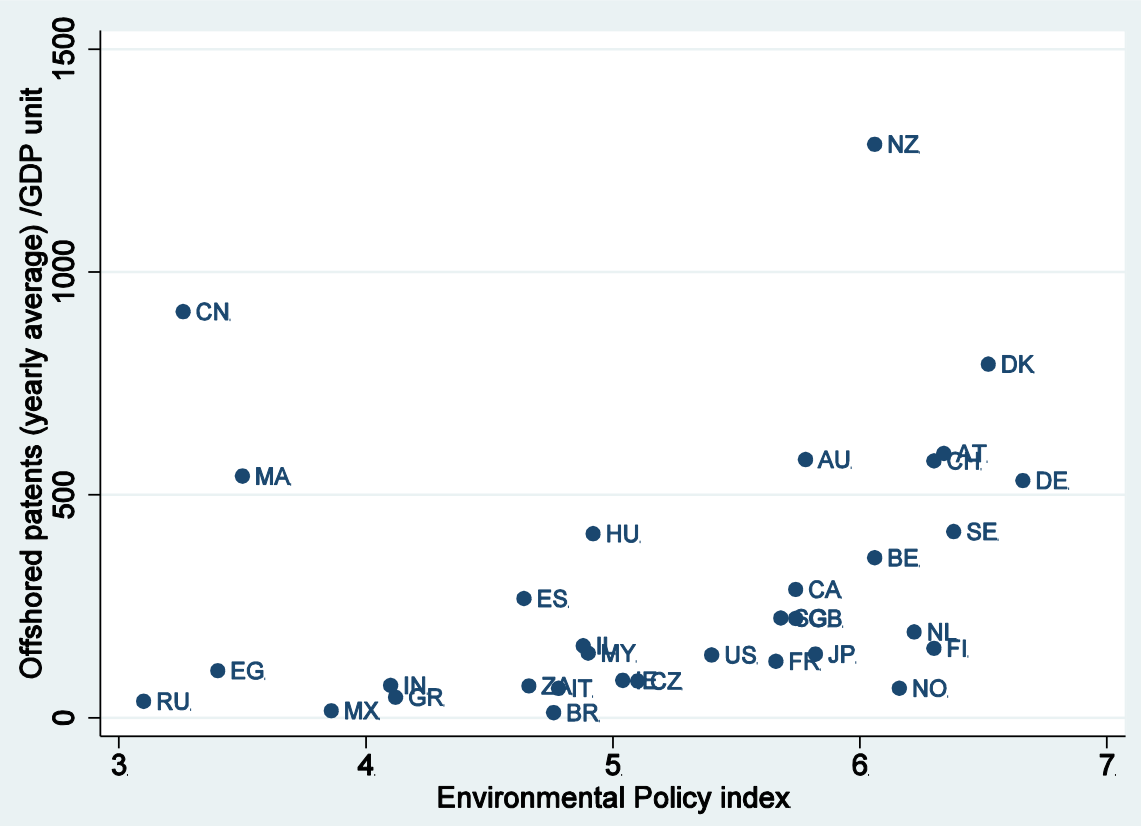

\section{Empirical strategy and results}

\subsection{Empirical strategy}

In this section we analyze the determinants of MNC green R\&D decision locations using multivariate econometric analysis. The choice of a firm for a given green R\&D location depends on various attributes of the host country. The attributes reflect the basic motives for locating 
green R\&D abroad identified in the literature as discussed in Section 2: namely adaptive R\&D, technology-sourcing and other costs of delocalizing R\&D.

Due to the adaptive R\&D motive we expect a positive relation between the decision to offshore green R\&D and the demand for environmental goods in the local market, captured by global market size and the level of environmental regulation. The market size of the host country is measured by GDP in current US dollars borrowed from the World Bank's World Development Indicators. Environmental policy stringency in the host country is measured by the Environmental Policy Index from the World Economic Forum described in Section 3. This index is limited, as it does not fully reflect the broad diversity of environmental regulations enforced in the local market. Also, there exists multicollinearity between the index of environmental stringency and country-specific variables such as GDP. Hence, we employ a GDP-adjusted index of environmental stringency, which is estimated as the residual after a regression of the index on GDP per capita and the constant term (see Ito and Wakasugi (2007) for similar issues with IPR indices). Despite these caveats, the environmental stringency index presents two main advantages for our purposes. First, it has a broad geographic coverage, including also nonOECD countries. This is a major advantage compared to other environmental policy variables generally used in the literature, such as tax-inclusive energy prices or government green R\&D expenditures, which are only available for OECD countries. Second, this index is general enough to be applied to the wide range of green technologies under consideration in our analysis.

Following the technology-sourcing motives, we approximate the technological capabilities of the host country by the Gross Domestic Expenditure on R\&D (GERD) as a percentage of GDP borrowed from the OECD Science and Technology Indicators. In other specifications, we also consider the share of population with tertiary education extracted from the OECD Science and Technology Indicators, as an alternative to GERD. Overall, we expect a positive relation 
between R\&D intensity in the host country and the decision of offshore green R\&D due to technology-sourcing motives. In addition, we also consider specifications where we add specific technological abilities in green R\&D measured by the relative stock of green patents as a percentage of the total stock of patents in the host countries. This indicator is constructed by borrowing data from the Patents Statistics database from the OECD on the number of triadic patent families in all technologies and in specific general environmental management technologies per inventor country and priority year. Here, again we expect a higher R\&D intensity in green technologies to attract MNC green R\&D offshoring activities.

Finally, we include additional variables to capture the cost of conducting R\&D abroad. For each firm-host country pair, we construct the differential between the wages of scientists and engineers (S\&E) at home and in the host country. S\&E wages are taken from the UBS Prices and Earnings reports which are published in detailed versions on a triennial base. The report contains wage information for major cities in developed and developing countries per precise job categories, including electrical engineers that represent the highly-skilled workforce (Demirbag and Glaister, 2010). For countries with multiple cities a non-weighted average was taken. We expect to find that MNCs are more likely to offshore green R\&D in host countries where the difference between home country and host country wages is large. Additionally, we also measure distances between two countries to capture the fact that costs of conducting $R \& D$ abroad are higher the further away the country is. Distance and a dummy for countries that share a common language are borrowed from the CEPII distance database. At last, to capture the costs of potential R\&D imitation, we use the Ginarte and Park (1997) index to capture the level of intellectual property rights in the various host countries (Park, 2008). To minimize multicollinearity issues and since the IPR index tends to be highly correlated with GERD, we only include it with specifications using the share of population with tertiary education. 
We consider 1,200 firms conducting green patenting activities outside their home country, where each firm has the possibility to locate in 30 potential host countries, resulting in about 36,000 observations. The descriptive statistics of our sample are given in Table 2.

Table 2: Summary statistics

\begin{tabular}{lllllll}
\hline Variable & Unit & Obs & Mean & $\begin{array}{l}\text { Std. } \\
\text { Dev }\end{array}$ & Min & Max \\
\hline Offshore Green & dummy & 35154 & 0.04 & 0.20 & 0 & 1 \\
Green Patents offshored & count & 35154 & 0.11 & 1.8 & 0 & 162 \\
GDP & 100. Bn USD & 35154 & 8043 & 12966 & 179 & 132926 \\
Env Str (adj) & index & 35154 & 0.19 & 0.59 & -1.6 & 1.3 \\
GERD per GDP unit & $\%$ & 35154 & 1.49 & 0.96 & 0.34 & 4.24 \\
\%Green/Total patent stocks & $\%$ & 35154 & 0.79 & 0.83 & 0 & 3.80 \\
\%Pop with tertiary education & $\%-p o i n t$ & 30621 & 4.3 & 1.04 & 0.57 & 6.41 \\
S\&E Wage differential & Gross USD/yr & 35154 & 29596 & 18327 & 0 & 70216 \\
Distance & km & 35154 & 7109 & 4590 & 9.55 & 19539 \\
Language & dummy & 35154 & 0.12 & 0.32 & 0 & 1 \\
IPR (year 2000) & index & 25251 & 4.06 & 0.48 & 2.96 & 4.66 \\
\hline
\end{tabular}

We consider the following baseline specification where the dependent variable is the probability that a firm i has offshored green patents to a given host country j over the 2004-2009 period, taking all control variables at their mean values over this period. ${ }^{8}$

To examine the determinants of green R\&D offshoring activity, we estimate the following model:

$\operatorname{Prob}\left(\right.$ Offshore $\left._{i j}\right)=\alpha+\beta_{1} \operatorname{lnGDP}_{j}+\beta_{2}$ EnvStr $_{j}+\beta_{3} R D_{j}+\beta_{4} \operatorname{lnDiffWages}_{i j}+\beta_{5} \operatorname{lnDIST}_{i j}+\beta_{6}$ Lang $_{j}+\beta_{7} E_{j}+\varepsilon$

Where $\operatorname{InGPD}$ denotes the logarithm of the GDP of the host country, EnvStr ${ }_{j}$ depicts the host country's adjusted environmental stringency index, $\mathrm{RD}_{\mathrm{j}}$ is a vector of host country characteristics capturing the (green) R\&D intensity of the host country, InDiffWages $\mathrm{s}_{\mathrm{ij}}$ is the logarithm of the wage differential between the home country of firm $i$ and the host country $j, \operatorname{InDIST} T_{i j}$ is the logarithm of the distance between the home and host country, LANG $_{j}$ is a dummy indicating whether both countries share a common language, $E U_{j}$ is a dummy indicating whether the destination country is a member of the European Union. Additional to this baseline specification,

\footnotetext{
${ }^{8}$ For the specification including the IPR index, we use the Ginarte Park index in the year 2000.
} 
we consider alternative models including IPRs and various indicators of R\&D intensity. Since our model varies across alternative locations choice, we estimate the baseline specification using a conditional logit, assuming that there is no correlation in unobserved factors over alternative destination countries. The conditional logit model is particularly appropriate in models of choice when an individual or firm makes a choice out of set of alternatives. Alternatively, we also consider a Tobit model on the number of green patents per location choice, since we have many firms-countries pairs where zero offshoring takes place.

\subsection{Results}

Table 3 presents the results of our econometric estimation. Column (1) presents the results of the basic model. Columns (2) and (3) include alternative specification of the host country's R\&D intensity, with column (3) including specific capabilities on green technologies. Column (4) includes specification with the IPR index. Finally, column (5) presents the result of the Tobit model for the non-censored observations for which we do observe positive green patents counts being offshored to the host country. Due to the difficulty of interpreting logit estimates, we only focus on the signs of the coefficient. Most of the coefficient show the expected signs and are highly significant. 
Table 3: Estimation results

\begin{tabular}{cccccc}
\hline & $(1)$ & $(3)$ & $(2)$ & $(4)$ & $(5)$ \\
& C.Logit & C.Logit & C.Logit & C.Logit & Tobit \\
\hline Log(GDP) & & & & & \\
& $1.207^{* * *}$ & $1.215^{* * *}$ & $1.071^{* * *}$ & $1.150^{* * *}$ & $5.474^{* * *}$ \\
& $(0.033)$ & $(0.034)$ & $(0.038)$ & $(0.048)$ & $(0.743)$ \\
Env. Stringency (adjusted) & $0.300^{* * *}$ & $0.292^{* * *}$ & $1.163^{* * *}$ & $0.941^{* * *}$ & $1.661^{* * *}$ \\
& $(0.069)$ & $(0.070)$ & $(0.081)$ & $(0.083)$ & $(0.376)$ \\
GERD & $0.164^{* * *}$ & $0.186^{* * *}$ & & & $0.595^{* * *}$ \\
& $(0.045)$ & $(0.049)$ & & & $(0.202)$ \\
\%Pop with Tertiary Education & & & $0.407^{* * *}$ & $0.491^{* * *}$ & \\
\% Green patents/ Total patents & & & $(0.041)$ & $(0.048)$ & \\
& & $0.095^{* *}$ & & & \\
Log(S\&E Wages Differential) & & $(0.047)$ & & & \\
& & & & & \\
Log(Distance) & $\left(0.354^{* * *}\right.$ & $0.350^{* * *}$ & $0.134^{* * *}$ & $0.054^{* *}$ & $1.389^{* * *}$ \\
& $-0.248^{* * *}$ & $-0.255^{* * *}$ & $-0.188^{* * *}$ & $-0.146^{* * *}$ & $-0.709^{* * *}$ \\
Language dummy & $(0.037)$ & $(0.038)$ & $(0.033)$ & $(0.038)$ & $(0.186)$ \\
& $1.174^{* * *}$ & $1.181^{* * *}$ & $1.298^{* * *}$ & $1.217^{* * *}$ & $5.413^{* * *}$ \\
Inv EU dummy & $(0.079)$ & $(0.079)$ & $(0.086)$ & $(0.104)$ & $(0.828)$ \\
& $0.388^{* * *}$ & $0.387^{* * *}$ & $1.278^{* * *}$ & $1.321^{* * *}$ & $2.921^{* * *}$ \\
IPR index & $(0.072)$ & $(0.071)$ & $(0.094)$ & $(0.099)$ & $(0.645)$ \\
& & & & $0.557^{* * *}$ &
\end{tabular}

Standard errors in brackets. Robust estimation with standard errors clustered at the firm level. ${ }^{* * *} p<0.01$. Logit estimates are reported. 
We find that firms are more likely to offshore green R\&D to host countries with more attractive attributes, as expected from our discussion of the literature. A firm's probability of offshoring green R\&D is positively associated with the size of the market in the host country. In all specifications, the coefficient on GDP is positive and highly significant. The stringency of environmental regulation in the local host country is also an important factor for MNCs green R\&D location decisions. This result has important policy implications since it implies that host countries can attract MNCs by creating a favorable policy regime towards environmental goods and technologies. A higher level of R\&D intensity in the host country also tends to attract green R\&D activities of MNCs, reflecting that the local scientific and technological potential is an important incentive for attracting foreign MNCs in line with the technologysourcing motives discussed in Section 2. In column (2), we also find that the relative importance of green technologies in the total stock of patents is also positively associated with a higher probability of green patents offshoring, suggesting that firms choose host countries with specific capabilities in green technologies. In all specifications we find that MNCs are attracted to countries for which there is a larger S\&E wage differential between the home and host country, implying that lower wages for S\&E abroad may drive the globalization of green R\&D. This likely explains the presence of low-wage countries, such as China and Morocco, as destination countries for green R\&D activities of MNCs. The probability of offshoring green R\&D decreases with geographical distance between the firm's home country and the host country, while sharing a common language increases the likelihood of offshoring green R\&D, underlying the importance of cultural factors in MNCs' R\&D location choices. The European Union appears as a particularly attractive location for locating green R\&D compared to all other countries. In column (4), we find that the level of IPRs protection is also important for the location decisions of MNCs, confirming the results of previous research (Ito and Wakasugi, 2007; Thursby and Thursby, 2006). Finally, our results are robust to using a Tobit model, as an alternative specification, as shown in column (5). 


\section{Conclusion and policy implications}

This study presented novel empirical evidence on the internationalization of green R\&D, a phenomenon on which systematic evidence was still lacking. Using data on inventors' addresses for a set of 1,200 MNCs patenting in green technologies over the 2004-2009 period, we find that about $18 \%$ of green patents result from MNCs' R\&D investments conducted outside their home countries. Our descriptive analysis shows that MNCs tend to locate their foreign green R\&D activities in other OECD markets but also in China, in particular in lighting and solar technologies. Our empirical analysis confirms the importance of factors, such as market size, R\&D intensity, S\&E wages, IPRs, and distance, as previously highlighted in the literature on the globalization of R\&D. Next to these factors, our analysis gives novel insights on the role of local environmental regulation and specific technological abilities in green technologies, as important drivers of MNCs' green R\&D location decisions.

Our results show that the changing global landscape of green innovation presents some new challenges for policymakers. As innovation is the main driver of economic growth, attracting R\&D investments from MNCs is high on the policy agenda of many countries. Policymakers in the host countries thus have an important role to play to attract MNCs' green R\&D investment. As MNCs are attracted to countries with a large market for green technologies, local environmental regulations are central to the creation of a local demand for green technologies. By giving incentives to consumers to buy environmental goods, environmental regulations make it attractive for MNCs to invest in the local country. With respect to a long-term investment such as innovation, the stability of environmental policy and level of commitment of the local governments will be particularly important.

In addition to creating local demand, stringent environmental policies are also necessary to increase the ability of local firms to absorb the knowledge developed in the R\&D labs of MNCs, since the level of absorptive capacity of the host country is an important condition 
for effective technology transfers from MNCs to local firms. Environmental policy plays an important role in encouraging local firms to engage in green innovation and, thus, to raise their capacity to absorb related knowledge. Foreign environmental policy is in general less effective than domestic environmental regulation in raising a country's green technological abilities (Peters et al, 2012).

Several studies have examined the emergence of China's innovative abilities in green technologies. Gallagher (2006) finds that in the 1990s few technology transfers related to emission-control technologies occurred between the US and Chinese joint-ventures in the automobile industry, mainly due to the absence of local environmental regulations in China. Also, while China's recent rapid development in the solar PV industry suggests that local firms can greatly learn from participating in global supply chains, most R\&D in the solar PV global value chain still resides in the hands of US and European MNCs, as discussed by Gallagher and Zhang (2013). The Chinese solar PV industry also recently experienced a downturn, as a result of lower environmental policy budgets in Germany and Spain, after the 2008 economic crisis, in the absence of a supporting local market for solar panels. China reacted in recent years by implementing a wide range of local public policies to help create a domestic market and support its new solar PV industry (Deutsch and Steinfield, 2013).

Besides environmental regulations, policymakers in host countries can design innovation policies to enhance the host country's R\&D infrastructure as MNCs' R\&D investments are attracted by a local host country environment that enables innovation capabilities, in the form of high-quality universities and research institutions and a good supply of scientists and engineers. Such innovation and technology policies include a broad range of instruments ranging from R\&D tax credits, not only for domestic firms but also for foreign affiliates of MNCs, to better governance and evaluation of public research, government-sponsored research and policies aiming to increase collaboration and interactions within national innovation systems (e.g. R\&D clusters, development of industry-science linkages, etc). Policies can be targeted to green 
technologies in particular, for instance in the form of R\&D subsidies for green technologies, demonstration projects on green technologies sponsored by governments' green R\&D expenditures, or R\&D clusters specific to green technologies, where MNCs affiliates can be located next to specialized local firms and start-ups. An example of such R\&D clusters is the Wind Power Cluster in the Jeonbuk Province in South Korea (Berg and Hassink, 2012).

Such policy implications are in line with discussions on the optimal policy mix between environmental and innovation policies. The environmental economics literature emphasizes the need to combine both environmental policy instruments (such as a carbon tax) with technology policy instruments (e.g tax credits for R\&D) to further enhance the development of green technologies (Jaffe et al., 2005). Due to the environmental externality and the public nature of knowledge, these policies work best when used in tandem. Nonetheless, environmental and innovation policies may not affect MNCs' decisions to offshore green technologies in a uniform way. We may for instance expect adaptive R\&D motives to be more important for existing green technologies that have already gained maturity in the home market. In this case, local environmental regulations will be effective in creating a local market for these mature technologies. Instead, technology-sourcing motives may be more important for less mature technologies for which additional and complementary knowledge is still needed. In this case, R\&D tax credits targeted at green technologies may be effective in attracting firms working on new emerging green technologies. In a similar vein, Florida (1997) finds that access to science is a more important motive in new emerging fields such as biotechnology, while market considerations were more relevant for more traditional sectors such as the automotive industry.

The availability of human capital is a central factor for international investment in R\&D. Public policies can thus play an important role in strengthening the domestic supply of human capital and improving the standing of educational policies and the careers of scientists and engineers. Although there has recently been some interest in policy circles for developing the 
supply of highly-skilled workers specific to green jobs, it is not yet clear how attractive these specialized workers will be for the private sector. Given the wide range of technological fields that form the green innovation base as discussed in the previous section, educational policies supporting a broad range of disciplines may provide a better match to the private sector needs than policies stimulating a narrow range of green skills.

Additionally, MNCs' green R\&D investment decisions may be affected by the level of IPRs in the host country. Stricter IPR enforcement may attract MNCs' R\&D investments. This is, however, likely to be mainly relevant for countries in which there is already a minimum amount of technological abilities so that domestic firms can compete with MNCs. At last, host country policymakers can also play a role in attracting green R\&D activities of MNCs by providing direct financial support or fiscal incentives to MNCs and implementing investment promotion policies (e.g. advertising).

The internationalization of green R\&D also has implications for international policymaking aiming to address climate change. Since MNCs own most of the technologies related to climate change mitigation, they are key players in the discussions related to the international diffusion of green technologies, notably to the developing world. While emissions from emerging and developing countries are rising, a recurrent question in the international climate change negotiations is how to encourage developing countries to participate into emissions mitigation objectives. Recently, the negotiations have focused on technology sharing to encourage developing countries to participate in the negotiation at a lower cost. International technology agreements can help to stimulate cooperation on green R\&D, as shown by the work of Hascic et al (2012) on co-inventions in green technologies.

Additionally, R\&D globalization is likely to affect the future development of institutions such as IPRs regimes and standardization processes, both at the national and international level. As the number of firms and countries involved in the technological development of green technologies increases (notably with new players from emerging countries), there will be an 
increasing need for discussion and reconfiguration of IPRs and standardization issues. The role of MNCs will be central in this process of shaping new institutions.

While our study provided a first analysis of the globalization of green R\&D, many issues are left unexplored for future work. Future research could aim to better understand how firms differ in their globalization strategies: why do certain firms concentrate green R\&D at home, while others choose to enter foreign markets - either by licensing their technology to local firms or by setting up an R\&D lab abroad? What type of firms' heterogeneity explains these various strategies? Future work could also look at how the geographic distribution of inventive activities varies with the characteristics of specific technologies: are more mature green technologies more likely to be offshored than emerging ones? How do the patterns of globalization of fossilfuel energy technologies differ from renewable energy ones? Finally, further research on international innovation and diffusion of green technologies would greatly benefit from improved data collection on local environmental regulations, in particular in developing countries. 


\section{References}

Abramovsky, L., R. Griffith, and H. Miller (2012) Offshoring high-skilled jobs: EU multinationals and domestic employment of inventors, CEPR Discussion Papers 8837.

Awate, S., M. Larsen and R. Mudambi (2012) EMNE catch-up strategies in the wind turbine industry: Is there a trade-off between output and innovation capabilities? Global Strategy Journal 2(3), 205-223

Brainard, S. (1997). An empirical assessment of the proximity-concentration trade-off between multinational sales and trade. American economic review 87.

Bosetti, V. and E. Verdolini (2012) Heterogeneous firms trading in ideas: An Application to Energy Technologies. Unpublished manuscript.

Cantwell, J. (1995) The globalisation of technology: what remains of the product cycle model? Cambridge Journal of Economics, 19(1): 159-174.

Cantwell, J. and L. Piscitello (1999). The emergence of corporate international networks for the accumulation of dispersed technological competences. MIR: Management International Review, 123-147.

Castellani, D., Palmero, A. J., \& Zanfei, A. (2011). The gravity of R\&D FDls. University of Burgos, Spain University of Urbino, Italy.

Chung, W., \& Yeaple, S. (2008). International knowledge sourcing: Evidence from US firms expanding abroad. Strategic Management Journal, 29(11), 1207-1224.

Cohen. W, R. R. Nelson, J. P. Walsh (2000) Protecting Their Intellectual Assets: Appropriability Conditions and Why U.S. Manufacturing Firms Patent (or Not), NBER Working Paper No. 7552.

Criscuolo, C. J.E. Haskel and M.J. Slaughter (2010) Global engagement and the innovation activities of firms. International Journal of Industrial Organization, 28: 191-202.

Dachs, B., and Pyka, A. (2010). What drives the internationalisation of innovation? Evidence from European patent data. Economics of Innovation and New Technology, 19(1), 71-86.

Dechezleprêtre, A., Glachant, M., Ménière, Y. (2012) What Drives the International Transfer of Climate Change Mitigation Technologies? Environmental and Resource Economics.

Dechezleprêtre A., M. Glachant, I. Hascic, N. Johnstone and Y. Meniere (2011) Invention and Transfer of Climate Change--Mitigation Technologies: A Global Analysis, Review of Environmental Economics and Policy, 5(1):109-130.

Dekker, T., H. Vollebergh, F. de Vries and C. Withagen (2012) Inciting protocols. Journal of Environmental Economics and Management. 
Devereux, Michael P. \& Griffith, Rachel \& Simpson, Helen, 2007. "Firm location decisions, regional grants and agglomeration externalities," Journal of Public Economics, Elsevier, vol. 91(3-4), pages 413-435, April.

Demirbag, M. and K. W. Glaister (2010). Factors determining offshore location choice for R\&D projects: A comparative study of developed and emerging regions. Journal of Management Studies, 47(8):1534-1560.

Deutch and Steinfeld (2013) A Duel in the Sun: The Solar Photovoltaics Technology Conflict between China and the United States, A Report for the MIT Future of Solar Study

Di Minin, A. and Palmberg, C. (2007) Why is Strategic R\&D (Still) Homebound in a Globalized Industry? The Case of Leading Firms in Wireless Telecom. Industry Studies Working Paper. 12

Dunning, J. H., and Narula, R. (1995). The R\&D activities of foreign firms in the United States. International Studies of Management \& Organization, 39-74.

Florida, R. (1997). The globalization of R\&D: Results of a survey of foreign-affiliated R\&D laboratories in the USA. Research policy, 26(1), 85-103.

Gallagher, K.S, (2006) Limits to leapfrogging in energy technologies? Evidence from the Chinese automobile industry, Energy Policy, 34(4) pp 383-394.

Gallagher, K.S and F. Zhang (2013) Innovation and Technology Transfer Across Global Value Chains: Evidence from China's PV Industry, Climate Technology \& Development Case Study. Climate \& Development Knowledge Network.

Griffith, R., Redding, S., and Van Reenen, J. (2004). Mapping the two faces of R\&D: productivity growth in a panel of OECD industries. Review of Economics and Statistics, 86(4), 883-895.

Håkanson, L., \& Nobel, R. (1993). Determinants of foreign R\&D in Swedish multinationals. Research Policy, 22(5), 397-411.

Haščič I. and N Johnstone and N. Kahrobaie, 2012. International Technology Agreements for Climate Change: Analysis Based on Co-Invention Data, OECD Working Paper.

Hall, B. (2011). The internationalization of R\&D. NBER Working Paper 2179941.

Hall, B. H. and Ziedonis, R.H (2001) The Patent Paradox Revisited: An Empirical Study of Patenting in the U.S. Semiconductor Industry, 1979-1995. Rand Journal of Economics. 32(1): 101-128.

Harhoff D. and G. Thoma (2010). Inventor location and the globalization of R\&D. LMU Muenchen and University of Camerino. 
Harhoff, D., Mueller, E., \& Van Reenen, J. (2012). What are the channels for technology sourcing? Panel data evidence from German companies (No. 187). Working Paper Series, Frankfurt School of Finance \& Management.

Henderson, R., A. Jaffe and M. Trajtenberg (1993) Geographic localisation of knowledge spillovers as evidenced by patent citations. Quarterly Journal of Economics, 108: 577-598.

Javorcik, B.S (2004) 'Dose foreign direct investment increase the productivity of domestic firms? In search of spillovers through backward linkages', American Economic Review 94(3): $605-627$

Jaffe A.B. (1986) Technological opportunity and spillovers of R\&D: Evidence from firms' patents, profits and market value. American Economic Review, 76(5), 984-1001.

Jaffe, A. B., Newell, R. G., \& Stavins, R. N. (2005). A tale of two market failures: Technology and environmental policy. Ecological Economics, 54(2), 164-174.

Johnstone, N., I. Hascic and D. Popp (2010) Renewable energy policies and technological innovation: Evidence based on patent counts. Environmental and Resource Economics, 45(1): 133-155.

Keller, W. (2004) International technology diffusion. Journal of Economic Literature, 42(3): 752782

Kellenberg, D. (2009). An empirical investigation of the pollution haven effect with strategic environment and trade policy. Journal of International Economics 78(2):242-255.

Kuemmerle, W. (1999). Foreign direct investment in industrial research in the pharmaceutical and electronics industries-results from a survey of multinational firms. Research Policy, 28(2), 179-193.

Lewin, A. Y., S. Massini, and C. Peeters (2009). Why are companies offshoring innovation? The emerging global race for talent. Journal of International Business Studies 40(6):901-925.

Narula, R., \& Zanfei, A. (2005). Globalisation of innovation. Handbook of Innovation, 318-45.

Odagiri, H., and Yasuda, H. (1996). The determinants of overseas R\&D by Japanese firms: an empirical study at the industry and company levels. Research Policy, 25(7), 1059-1079.

OECD (2008) Attractiveness for innovation: Location factors for international investment. Paris. OECD (2010) Measuring Innovation: A New Perspective. Paris 
Patel, P., and Vega, M. (1999). Patterns of internationalization of corporate technology: location vs. home country advantages. Research Policy, 28(2), 145-155.

Peters, M., Schneider, M., Griesshaber, T., \& Hoffmann, V. H. (2012). The impact of technologypush and demand-pull policies on technical change-Does the locus of policies matter?. Research Policy, 41(8), 1296-1308.

Popp, D. (2002) Induced Innovation and Energy Prices. American Economic Review, 92(1): 160-180.

Reger, G. (2002) Internationalisation of research and development in western European, Japanese and North American multinationals, International Journal of Entrepreneurship and Innovation Management, 2(2), 164-185

Thursby, M., \& Thursby, J. (2006). Here or There?: A Survey of Factors in Multinational R\&D Location--Report to the Government-University-Industry Research Roundtable. National Academies Press.

UNCTAD (2005) World Investment Report 2005: Transnational Corporations and the Internalization of R\&D. United Nations, New York and Geneva.

Wakasugi, R. and B. Ito (2007) What factors determine the mode of overseas R\&D by multinationals? Empirical evidence. Research Policy, 36, pp 1275-1287.

World Bank (2012) Green growth, technology and innovation. World Bank, Washington D.C. 